Osichev Alexander, Ph. D (Tech.), Docent, Professor; Tel. (+38)0668414055; E-mail: osichev.kafedra@gmail.com Tkachenko Andrii, Ph. D. (Tech.); Tel.(+38)066-327-14-55; E-mail: Andrii.Tkachenko@khpi.edu.ua National Technical University «Kharkiv Polytechnic Institute», st. Kyrpychova, 2, Kharkiv, Ukraine, 61002

\title{
INFLUENCE OF FRICTION IN THE ARMORED FACE CONVEYOR CHAIN ON DYNAMICS AND ENERGY EFFICIENCY
}

\begin{abstract}
The range of values of the coefficient of resistance to movement of the chain of typical longwall armored face conveyors and the coefficient of inner viscous friction in the chain, both immersed in the moving load and during the idle run of the conveyor, is estimated. The computer model of the conveyor is built as a multi-mass elastic-viscous stretched closed chain without sag with the number of masses $n=200$ and one induction drive motor located in the head of the conveyor. Using the constructed model, three-dimensional space-time dynamic characteristics of speeds and forces in the chain of the CP72 longwall armored face conveyor are obtained. Start up to rated speed $v \approx 1 \mathrm{~m} / \mathrm{s}$ and the working process is simulated with an unloaded conveyor. The spatial form of frictional self-oscillations in the model with distributed parameters is shown. The resonance frequencies and amplitudes of oscillations of the efforts in the circuit and the length of the corresponding spatial waves have been determined. It was found that at the first and second resonance frequencies, self-oscillations are not excited, since the damping effect of the electric drive is quite pronounced in this frequency band. The direct connection of vibration amplitudes with the energy efficiency of the conveyor electric drive is indicated.
\end{abstract}

Keywords: armored face conveyor, internal viscous friction, coefficient of resistance to movement, frictional selfoscillations, model, dynamic characteristics, forces in the chain, 3D-graphs.

Осичев Олександр Васильович, канд. техн. наук, доц., професор; Тел. (+38)066-841-40-55; E-mail: osichev.kafedra@gmail.com

Ткаченко Андрій Олександрович, канд. техн. наук; Тел.(+38)066-327-14-55; E-mail: Andrii.Tkachenko@khpi.edu.ua Національний технічний університет «Харківський політехнічний інститут», вул. Кирпичова, 2, Харків, Україна, 61002

\section{ВПЛИВ ТЕРТЯ В ЛАНЦЮЗІ СКРЕБКОВОГО КОНВЕСРА НА ЙОГО ДИНАМІКУ І ЕНЕРГОЕФЕКТИВНІСТЬ}

\begin{abstract}
Анотація. Оиінений діапазон значень коефіцієнта опору переміщенню ланцюга скребкових конвеєрів $i$ коефіцієнта внутрішнього в'язкого тертя. Отримано тривимірні просторово-часові динамічні характеристики швидкостей $і$ зусиль в ланцюзі скребкового конвеєра СР72. Показана просторова форма фрикційних автоколивань в моделі з розподіленими параметрами. Зазначено на прямий зв'язок амплітуд коливань з енергоефективністю електроприводу конвеєра.

Ключові слова: скребковий конвеєр, внутрішнє в'язке тертя, коефічієнт опору переміщенню, фрикційні автоколивання, модель, динамічні характеристики, зусилля в ланцюзі, 3D-графіки.
\end{abstract}

Осичев Александр Васильевич, канд. техн. наук, доц., профессор; Тел. (+38)066-841-40-55; E-mail: osichev.kafedra@gmail.com

Ткаченко Андрей Александрович, канд. техн. наук; Тел.(+38)066-327-14-55; E-mail: Andrii.Tkachenko@khpi.edu.ua

Национальный технический университет «Харьковский политехнический институт», ул. Кирпичева, 2 , Харьков, Украина, 61002

\section{ВЛИЯНИЕ ТРЕНИЯ В ЦЕПИ СКРЕБКОВОГО КОНВЕЙЕРА НА ЕГО ДИНАМИКУ И ЭНЕРГОЭФФЕКТИВНОСТЬ}

Аннотация. Оченен диапазон значений коэффициента сопротивления перемещению цепи скребковых конвейеров и коэффициента внутреннего вязкого трения. Получены трехмерные пространственновременные динамические характеристики скоростей и усилий в цеепи скребкового конвейера СР72. Показана пространственная форма фрикционных автоколебаний в модели с распределенными параметрами. Указано на прямую связь амплитуд колебаний с энергоэффективностью электропривода конвейера.

Ключевые слова: скребковый конвейер, внутреннее вязкое трение, коэффициент сопротивления перемещению, фрикционные автоколебания, модель, динамические характеристики, усилия в иепи, 3D-графики.

Formulation of the problem. One of the central problems of practical construction of adequate mathematical models of complex electromechanical systems is most often the lack of values of their parameters estimated at least within the framework of engineering measurement 
accuracy. Therefore, when obtaining a description of systems, it is often necessary to base on some generalized or averaged values of parameters known from literary sources. In order, to trust the simulation results in this case, it is necessary to conduct a whole series of test calculations, comparing the obtained dynamic processes with these averaged parameters, with a description of the dynamics and technological process features, and rather rare published fullscale waveforms. Only then can the values of the model parameters specified in this way be accepted for further modeling. Thus, the task of the article is to determine the values of the parameters of the longwall armored face conveyor model, which could be use in the future for modeling and evaluating dynamic processes. Then, depending on the obtained values of amplitudes, vibration frequencies, and the rate of their attenuation, it will be possible to draw adequate conclusions about both the dynamic properties of the conveyor and its energy efficiency. Energy efficiency, in particular, is negatively affected by temperature and electromagnetic torque fluctuations generated not only in the power supply circuit (as it was usually considered [1] when designing DC electric drives), but also along the load perturbation chain.

Analysis of recent research and publications. Difficult to identify parameters, in particular, for longwall armored face conveyor, include the values of the drag coefficient of the chain and the coefficient of internal viscous friction in it. At the same time, the range of variation of these coefficients is so wide that it affects even the form of dynamic processes in mechanisms. Thus, the coefficient of inner friction in the rolling of steel is equivalent to the logarithmic decrement $\lambda=0.03 \div 0.07$ [2], it is for the kinematic links of different actuators correspond to the decrement $\lambda=$ of $0.1 \div 0.3$ [3], the traction on conveyors according to some authors [4] to spare conveyors $\lambda=0.24$ and $\lambda=0.27$ for and loaded, and other $\lambda=0.004$ [5] in their traction chain.

A similar state of affairs with the coefficient of drag resistance of the armored conveyor chain is aggravated by the influence of coal grade, humidity, conveyor vibration level, etc. on its value [5].

The forces that occur in the working body of the armored conveyor depend on the coefficient of resistance to movement to the $\mathrm{k}_{\mathrm{fr}}$ of the working body and the load along the conveyor belt. It is known that the drag coefficient decreases with increasing transport speed [6,7]. The main reasons for this are transverse vibrations of the grid, friction itself, the presence of spatial flexibility of the chain, as well as the inertia of its movement due to the drive sprocket [4]. Numerous experiments have shown that, as a result, the actual coefficient of drag resistance of the traction chain and load varies along the length of the armored conveyor and depends on the amplitude of its transverse vibrations. Therefore, to simplify the tasks of studying armored conveyors, we take a certain average value [4] - the dependence of the coefficient on the speed of chain movement, shown in Fig. 1.
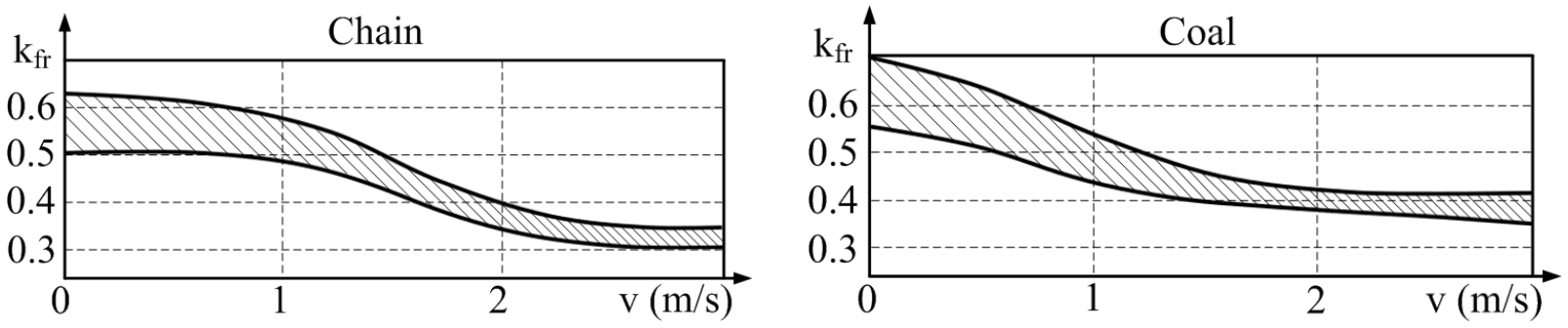

Fig. 1. Graphs of the dependence of the resistance coefficient $\mathrm{k}_{\mathrm{fr}}$ on the speed of the working body

Three-dimensional space-time transition characteristics of velocities in chain links at $\mathrm{k}_{\mathrm{fr}}=$ const were obtained earlier for the CP72 scraper conveyor and presented in [8].

Purpose of the study. To determine designed computer model the effect of internal viscous friction in the chain armored conveyor to the frequency, amplitude and rate of decay of dynamic processes to produce adequate insights for further modeling of the probability of impulse circuit in case of jamming of the conveyor, the correctness of selection of power of the drive motor at the stage of mold designation of the electric drive (energy efficiency and 
efficiency of the pipeline with nominal loading), the correct setup of the current controllers, flux and velocity controllers induction drive in terms of bandwidth selection, etc.

Presentation of the main research material. The computer model developed by the authors of the CP72 conveyor under consideration, produced by the "Svet Shakhtera" plant in Kharkiv, is presented by a structural diagram in Fig. 2.

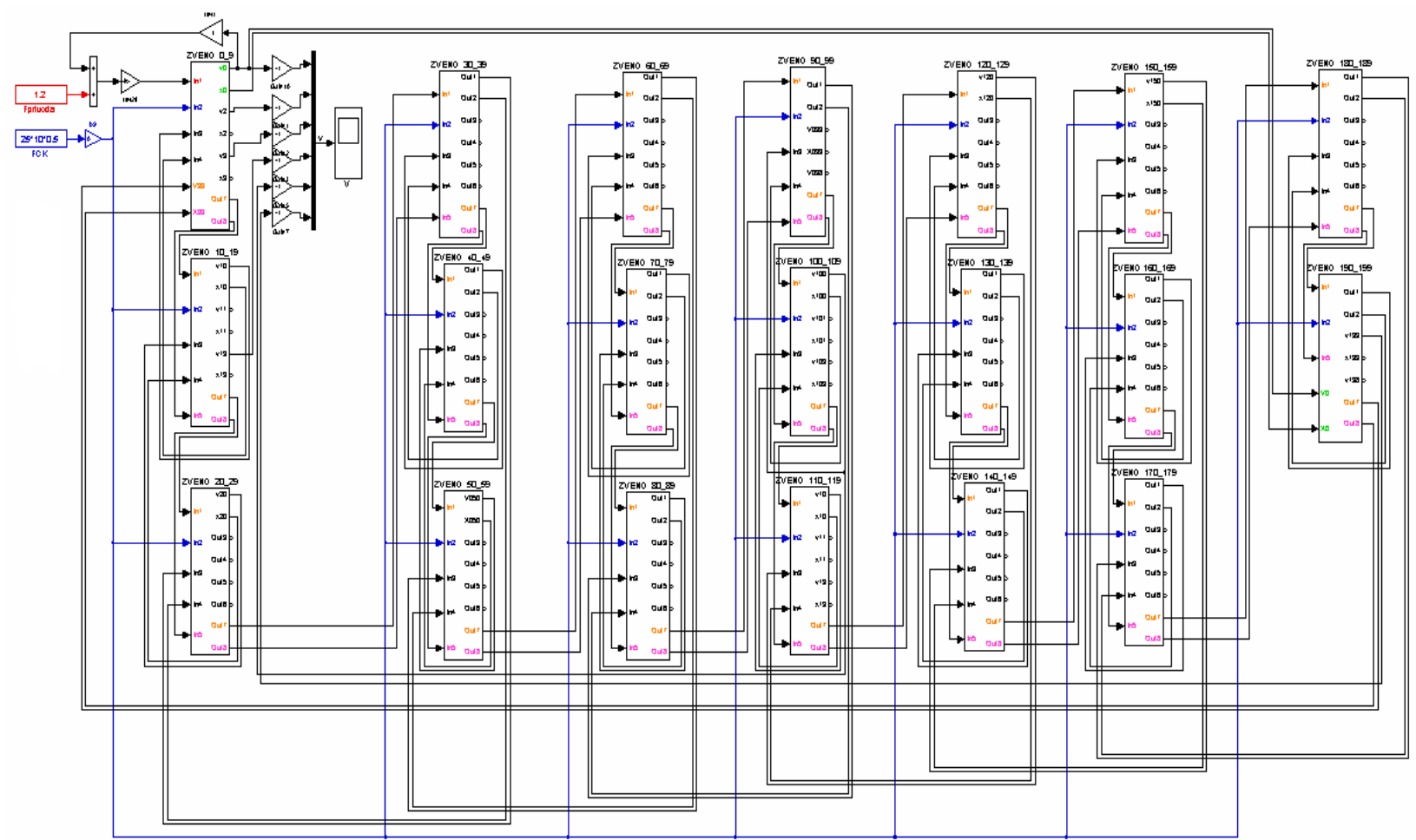

Fig. 2. Block diagram of the 200-mass model of the induction electric drive of the CP72 armored face conveyor for Matlab

Three-dimensional space-time dynamic characteristics of speeds and forces in the chain, calculated in the model taking into account the falling section of the friction characteristic according to Fig. 1 for the CP72 armored conveyor, are shown in Fig. 3, 4. The computer model corresponds to a kinematic scheme with a single drive induction motor located at the head of the conveyor. The simulated chain in this experiment has elasticity under tension and compression, and there is no sagging. The chain viscosity is assumed to be small: $\beta=500 \mathrm{~N} \cdot \mathrm{s} / \mathrm{m}$, which corresponds to a logarithmic decrement $\lambda=0.03$. Starting up to the nominal speed $v \approx 1 \mathrm{~m} / \mathrm{s}$ and the operating process is modeled when the conveyor is not loaded.

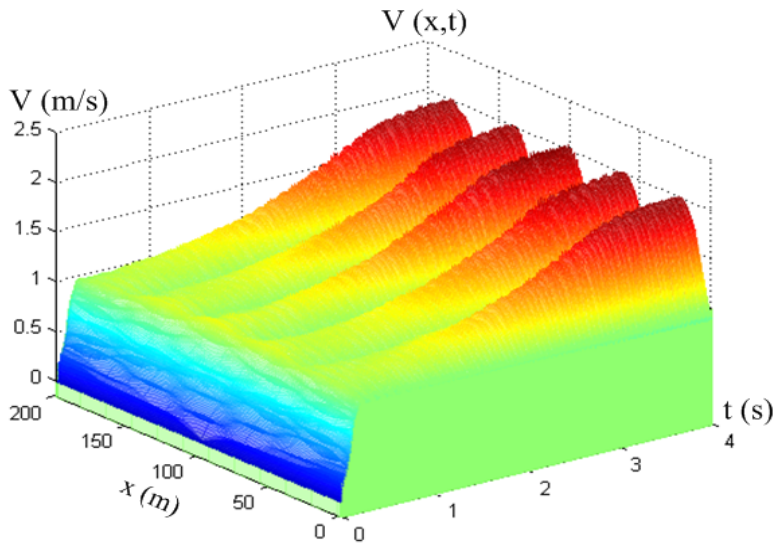

a)

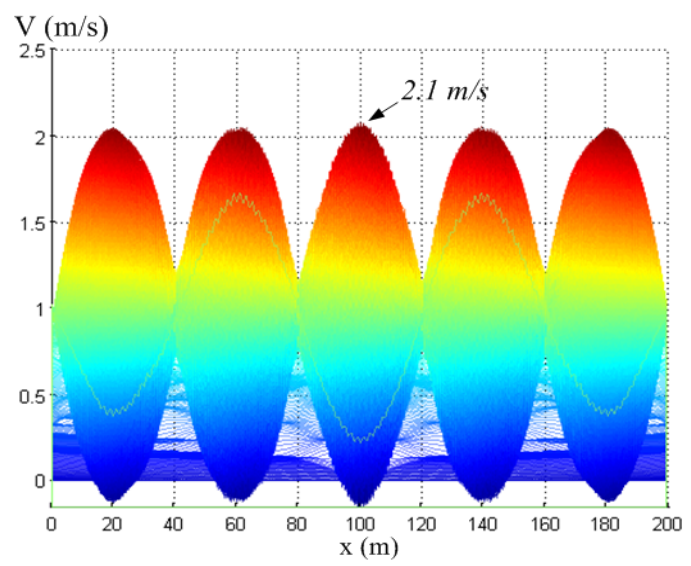

b)

Fig. 3. Three dimensional representation of dynamic processes velocities of chain elements 


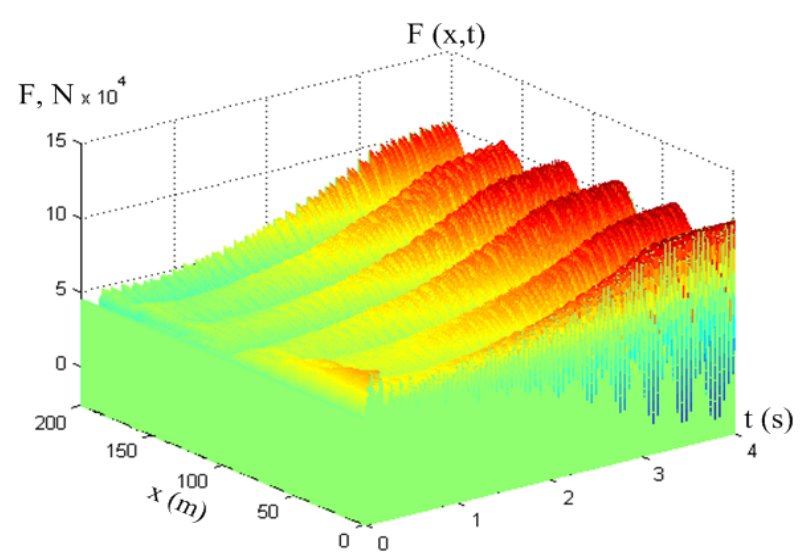

a)

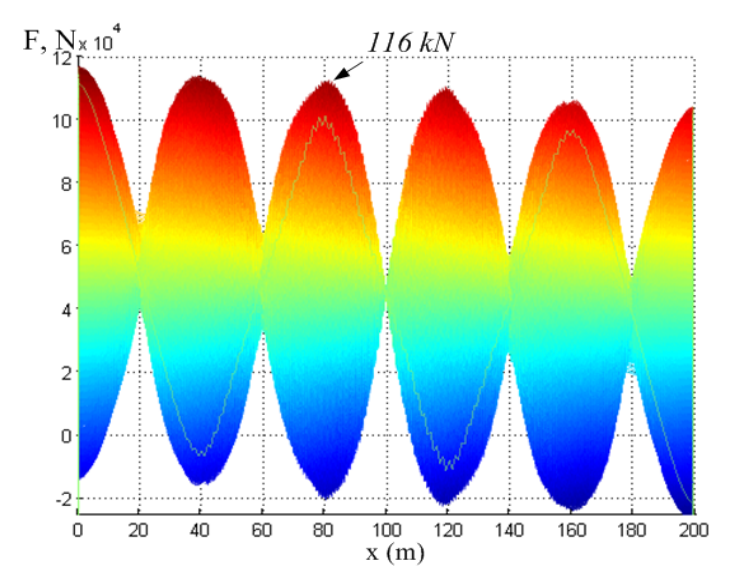

b)

Fig. 4. Three-dimensional representation of dynamic processes of forces in a chain

From Fig. 3 it can be seen that self-oscillations (of velocities) occur and are set in the working body of the conveyor. Fluctuations are non-relaxation in nature. At the same time, the maxima of their amplitudes are located in the antinodes of standing waves and reach the value $\mathrm{v}=2 \mathrm{~m} / \mathrm{s}$, which is twice the working speed of the conveyor.

The least vibrations occur naturally in the nodes of standing waves. The length of the standing wave of self-oscillations is $80 \mathrm{~m}$. The self-oscillation frequency is close to the thirde natural frequency of the mechanical system and is approximately $38 \mathrm{~Hz}$. Vibrations are not excited at the first and second resonant frequencies of the too, since the damping effect of the electric drive is quite pronounced in this frequency passband. Similar processes in armored conveyors with slightly smaller amplitudes are well known from observations of operating installations [4].

From Fig. 4 shows that the resulting self-oscillations cause significant dynamic loads in the chain links. The maximum load falls on the links located near the drive station and is equal to $118 \mathrm{kN}$. This value is less than the breaking force of the working body, equal to $252 \mathrm{kN}$, and does not lead to its rush. However, studies [4] show that the chain of a armored conveyor collapses mainly as a result of prolonged periodic loads that are significantly lower than the breaking force. The reason for this is fatigue phenomena in the metal that occur during the operation of the conveyor. The average service life of the chain is $5 \div 8$ months, and in a humid environment 1-1.5 months [4].

It should be noted that for speed fluctuations with a frequency of $38 \mathrm{~Hz}$ and an amplitude of $1 \mathrm{~m} / \mathrm{s}$, the amplitude of acceleration fluctuations will be $2 \cdot \pi \cdot 38=238 \mathrm{~m} / \mathrm{s}^{2}$. At such accelerations of the scrapers, it will slowly break away from the pushed coal, and then, accelerating, it will hit it in the case of transporting a small amount of coal. This effect is not included in the model, which describes the processes either at idle speed of the conveyor, or under the condition that the transported coal is sufficiently tightly packed between the scrapers at an average conveyor load. With a large amount of coal, a tunnel effect occurs [9] (movement of coal layers relative to each other), which can be taken into ac-count in the model by participation coefficients in the same way [4].

The steepness of the falling section of the friction curve, as well as the coefficient of inner viscous friction $\beta$ of the traction chain, significantly affect the nature of processes in the system. Thus, at $\beta=6000 \mathrm{~N} \cdot \mathrm{s} / \mathrm{m}$ (i.e., with a sufficiently large damping $\lambda=0.36$ ), there are practically no self-oscillations in the system (Figs. 5, 6). The transients are similar to those obtained in the model at $\beta=500 \mathrm{~N} \cdot \mathrm{s} / \mathrm{m}$, but without taking into account the incident section of the friction characteristic.

In various systems, the coefficient of viscous friction is in the range of $50-5000 \mathrm{~N} \cdot \mathrm{s} / \mathrm{m}$ [2-5]. For further studies, we will take $\beta=500 \div 1000 \mathrm{~N} \cdot \mathrm{s} / \mathrm{m}$ as real, but the least favorable from the point of view of the magnitude of dynamic forces that are supposed to be evaluated. 


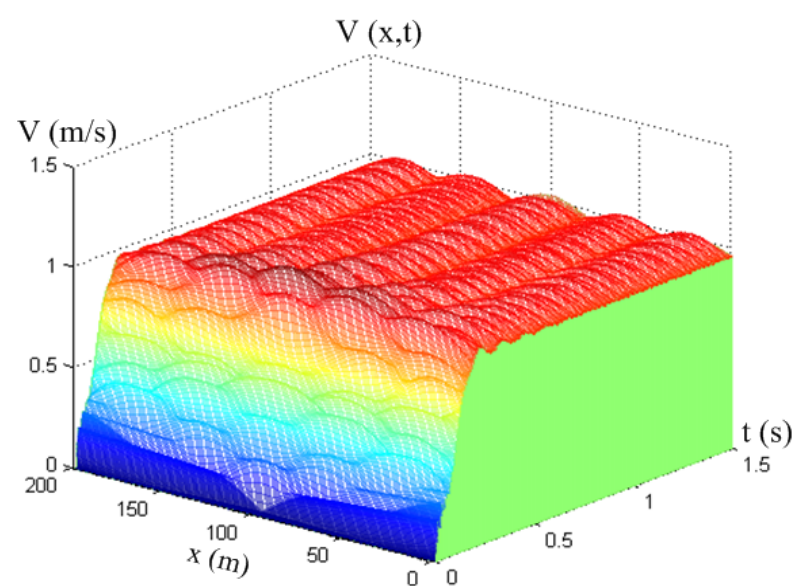

a)

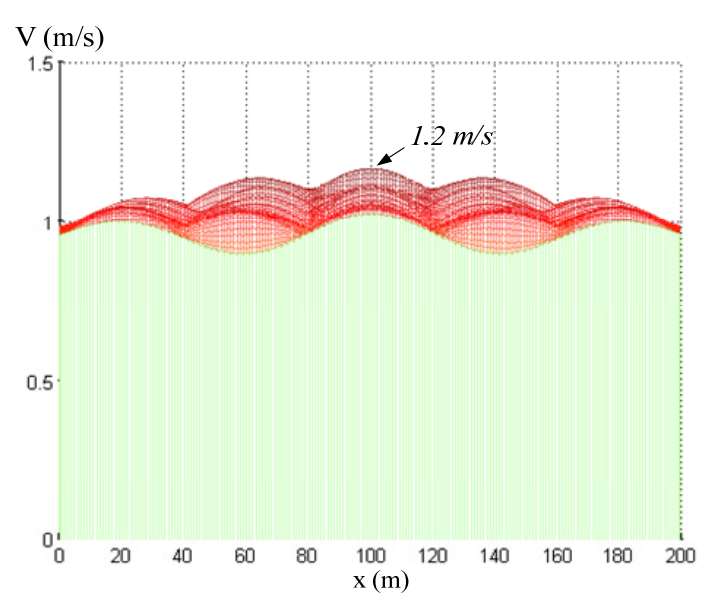

b)

Fig. 5. Three dimensional representation of dynamic processes velocities of chain elements

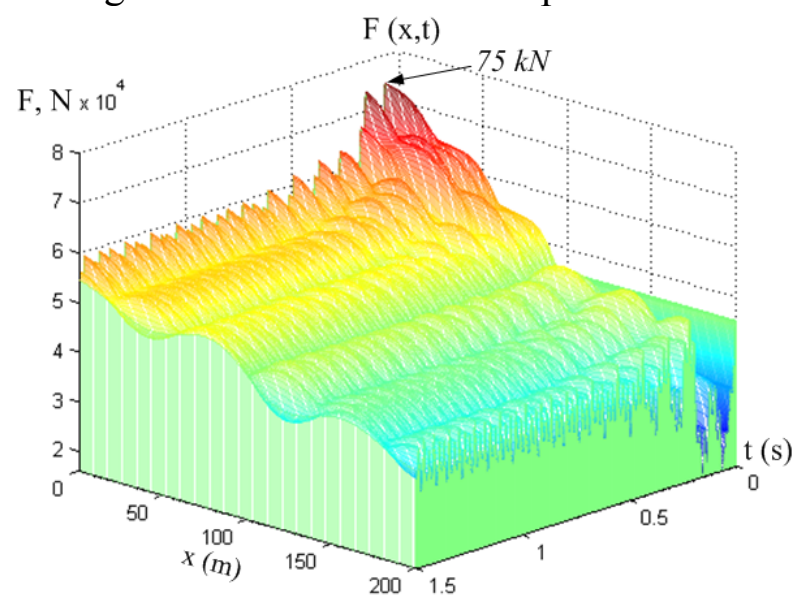

a)

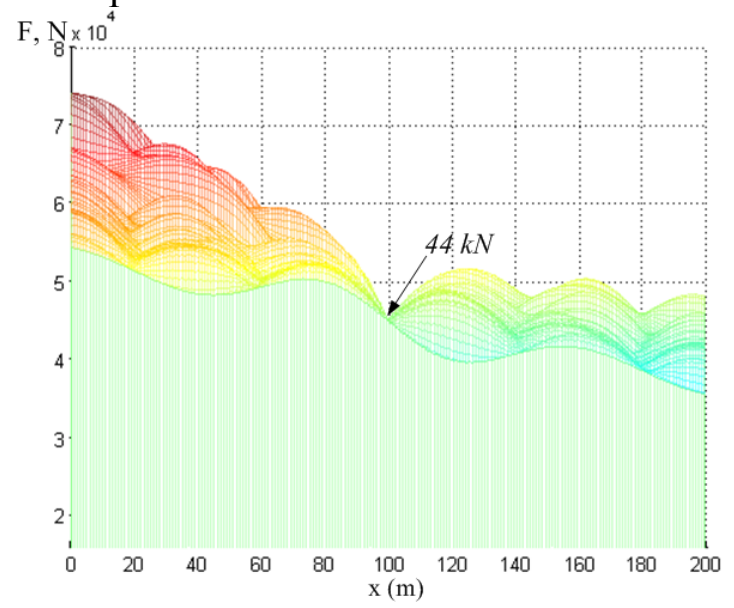

b)

Fig. 6. Three-dimensional representation of dynamic processes of forces in a chain

The steepness of the falling section of the friction curve, as well as the coefficient of inner viscous friction $\beta$ of the traction chain, significantly affect the nature of processes in the system. Thus, at $\beta=6000 \mathrm{~N} \cdot \mathrm{s} / \mathrm{m}$ (i.e., with a sufficiently large damping $\lambda=0.36$ ), there are practically no self-oscillations in the system (Figs. 5, 6). The transients are similar to those obtained in the model at $\beta=500 \mathrm{~N} \cdot \mathrm{s} / \mathrm{m}$, but without taking into account the incident section of the friction characteristic.

\section{Conclusions from the study.}

1. For the CP72 longwall armored face conveyor model, the velocity dependence of the displacement resistance coefficient curve can be taken into account according to Figure 1, and the internal viscous friction coefficient can be assumed in the range of $500 \leq \beta \leq 1000 \mathrm{~N} \cdot \mathrm{s} / \mathrm{m}$. At the same time, the dynamic processes in the pipeline model correspond to those known from literature sources, and it can be used for further research in various modes.

2. The calculated dynamic processes in the model, taking into account the falling section of the pipeline and external friction, indicate that self-oscillations (velocities) occur and are established in the working body of the conveyor. Fluctuations are non-relaxation in nature. At the same time, the maxi-ma of their amplitudes are located in the antinodes of standing waves and reach the value $\mathrm{v}=2 \mathrm{~m} / \mathrm{s}$, which is twice the working speed of the conveyor.

3. The length of the standing wave of self-oscillations is $80 \mathrm{~m}$. The self-oscillation frequency is close to the third natural oscillation frequency of a mechanical system and is approximately $38 \mathrm{~Hz}$.

4. At the first and second resonant frequencies, self-oscillations are not excited, since 
the damping effect of the electric drive is quite pronounced in this frequency band. Similar processes in armored conveyors with slightly smaller amplitudes are well known from observations of existing installations.

5. The maximum load falls on the links located near the drive station and is equal to 118 $\mathrm{kN}$. This value is less than the breaking force of the working body, equal to $252 \mathrm{kN}$, and does not lead to its rush. However, as studies show [4], the destruction of the scraper chain on the conveyor occurs mainly as a result of prolonged periodic loads that are significantly lower than the breaking force. The reason for this is fatigue phenomena in the metal.

6 . The steepness of the falling section of the friction curve, as well as the coefficient of internal viscous friction $\beta$ of the traction chain, significantly affect the nature of processes in the system. Thus, at $\beta=6000 \mathrm{~N} \cdot \mathrm{s} / \mathrm{m}$ (i.e., with sufficiently large damping with a logarithmic decrement $\lambda=0.36$ ), there are practically no self-oscillations in the system.

7. For speed fluctuations with a frequency of $38 \mathrm{~Hz}$ and an amplitude of $1 \mathrm{~m} / \mathrm{s}$, the amplitude of acceleration fluctuations will be $2 \cdot \pi \cdot 38=238 \mathrm{~m} / \mathrm{s}^{2}$. This frequency is within the bandwidth of modern controlled electric drives. Therefore, these fluctuations will cause corresponding fluctuations in the motor currents and noticeably increase its heating. The latter effect should be taken into account when choosing an energy-efficient electric conveyor drive when designing or upgrading it.

Список використаної літератури:

1. Башарин А. В., Голубев Ф. Н., Кепперман В. Г. Примеры расчетов автоматизированного электропривода. - Л.: Энергия, 1971. - 439 с.

2. Пановко Я. Г. Основы прикладной теории колебаний и удара. - Л.: Политехника. 1990. - 272 с.

3. Чиликин М. Г., Ключев В. И., Сандлер А. С. Теория автоматизированного электропривода. М.: Энергия, 1979. - 616 с.

4. Чугреев Л. И. Динамика конвейеров с цепным тяговым органом. - М., “Недра”, 1976. - 160 с.

5. David H. Wauge. Modeling of an Armored Face Conveyor. Department of Mechanical Engineering The University of Queensland. Masters of Engineering Science Thesis. August 19, 2002.

6. Перминов Г. И. Влияние скорости транспортирования на сопротивление движению тягового органа скребкового конвейера. - В кн.: Транспорт шахт и карьеров. - М., “Недра”, 1971. - с. 154-157.

7. Guder H. Untersuchungen zu Treigen der Auslegung und sostruhtion von Ketten Kratrerforderern. Glukauf - Forschung. 1969. 30, s. 426-430.

8. Осичев А. В., Ткаченко А. А. Разработка семейства компьютерных моделей для исследования динамических процессов в электроприводах скребковых конвейеров // Вісник Кременчуцького державного політехнічного університету імені М. Остроградського. - Кременчук: КДПУ, 2008. - 3/2008(50) ч. 2. - С.154-157.

9. Lloyd A. Morley, Jeffrey L. Kohler, Harold M. Smolnikal. A Model for Predicting Motor Load for an Armored Face-Conveyor Drive. // IEEE TRANSACTIONS ON INDUSTRY APPLICATIONS. 1988. S. 649 - 659.

\section{References:}

1. Basharin A. V., Golubev F. N., Kepperman V. G. Primery raschetov avtomatizirovannogo elektroprivoda L. Energiya, 1971, 439 p.

2. Panovko Ya. G. Osnovy prikladnoy teorii kolebaniy i udara. L. Politekhnika. 1990, 272 p.

3. Chilikin M. G., Klyuchev V. I., Sandler A. S. Teoriya avtomatizirovannogo elektroprivoda. M. Energiya, 1979, $616 \mathrm{p}$.

4. Chugreyev L. I. Dinamika konveyyerov s tsepnym tyagovym organom. M. Nedra, 1976. 160 p.

5. David H. Wauge. Modeling of an Armored Face Conveyor. Department of Mechanical Engineering The University of Queensland. Masters of Engineering Science Thesis. August 19, 2002.

6. Perminov G. I. Vliyaniye skorosti transportirovaniya na soprotivleniye dvizheniyu tyagovogo organa skrebkovogo konveyyera. - V kn.: Transport shakht i kar'yerov. M. Nedra, 1971. pp. 154-157.

7. Guder Kh. Untersuchungen zu Treigen der Auslegung und sostruhtion fon Ketten Kratrerforderern. Glyukauf - Forshung. 1969. 30, pp. 426-430.

8. Osichev A. V., Tkachenko A. A. Razrabotka semeystva komp'yuternykh modeley dlya issledovaniya dinamicheskikh protsessov $\mathrm{v}$ elektroprivodakh skrebkovykh konveyyerov. Visnik Kremenchuts'kogo derzhavnogo politekhnichnogo universitetu imeni M. Ostrograds'kogo. - Kremenchuk: KDPU, 2008. 3/2008(50) ch. 2. pp. 154-157.

9. Lloyd A. Morley, Jeffrey L. Kohler, Harold M. Smolnikal. A Model for Predicting Motor Load for an Armored Face-Conveyor Drive. IEEE TRANSACTIONS ON INDUSTRY APPLICATIONS. 1988, pp. 649 - 659. 